Magdalena Razik-Trziszka ur. 1987 r., absolwentka Uniwersytetu Wrocławskiego na kierunkach politologia i dziennikarstwo. Ukończyła również podyplomowe studia na Uniwersytecie Ekonomicznym. Udzielała się w samorządzie studenckim. Zawodowo zwiqzana z administracja publiczna. W wyborach samorzadowych w 2014 r. uzyskała mandat radnej Rady Miejskiej Wrocławia VII kadencji (2014-2018). Pełni funkcję m.in. przewodniczacej komisji statutowej, wiceprzewodniczqcej komisji rodziny, zdrowia i spraw socjalnych.

\section{Samorząd to żywy i twórczy podmiot}

Z Magdaleną Razik-Trziszką rozmawia Rafał Nowakowski

Rafał Nowakowski: Jest Pani jedna z najmłodszych radnych Rady Miejskiej Wrocławia VII kadencji. Od lat zasiadaja w tym organie mocno doświadczeni i obyci w tematyce samorzadowej radni. Jak czuje się Pani w tym towarzystwie i jak układaja się Wasze relacje oraz współpraca?

Magdalena Razik-Trziszka: Nasza współpraca układa się bardzo ciekawie. Taki układ w Radzie Miejskiej daje możliwość łączenia zarówno doświadczenia, jak i stateczności z energią i dynamizmem młodych radnych. Racjonalność i brawura to interesujące połączenie. Faktycznie w tej kadencji mamy wyjątkowo dużą liczbę radnych sprawujących swój mandat po raz pierwszy. Jest to więc dość odmłodzona rada, co widać po średniej wieku. Zapraszam do lektury Urzędu Statystycznego Wrocławia, który prezentuje od lat te dane w swoich publikacjach. Osobiście staram się czerpać, mądrości, wiedzy i praktyki kolegów i koleżanek „weteranów” wrocławskiego samorządu. Nasze relacje układają się bardzo dobrze. Współpraca prezentuje się ciekawie, choć nie brak napięć i różnic na dyskutowane tematy. Czasami sprawy stają wręcz na ostrzu noża, ale grunt to rozmawiać, różnić się i wypracowywać kompromisy. Jest to nasz wspólny sukces, zważywszy, że miasto to żywy i dynamiczny organizm, a więc problemów i kontrowersji jest bez liku.

R.N.: Wchodząc do Rady Miejskiej Wrocławia, miała już Pani jednak spore doświadczenie wyniesione z pracy w administracji publicznej, wolontariacie czy wcześniej w działalności na Uniwersytecie Wrocławskim.

M.R.-T.: Chronologicznie w pierwszej kolejności wymieniłabym okres studiów. Studiując dwa fakultety, angażując się w samorząd studentów, w działalność społeczną,

Miasto. Pamięć i Przyszłość 1 (2016) ISSN 2543-621X 
musiałam szybko nauczyć się sprawnie dzielić czas i radzić z dużą liczbą różnych zajęć. To była pierwsza szkoła kompromisu i dobrej organizacji pracy. A byłam w tym okresie przewodniczącą Wydziałowej Rady Samorządu Studenckiego na Wydziale Nauk Społecznych UWr i to właśnie tam pierwszy raz zetknęłam się z koniecznością godzenia partykularnych interesów. Redagowałam jednocześnie Salon Polityczny w uczelnianym piśmie "Uniwersal". W ramach wolontariatu zajmowałam się problematyką niepełnosprawności i szeroko rozumianą sferą społeczną. Z pracą w administracji publicznej zetknęłam się po raz pierwszy w pracy na stanowisku asystenta wicewojewody dolnośląskiego, a następnie w pracy eksperta w Biurze Wojewody. To wówczas miałam możliwość poznania funkcjonowania rządowej administracji terenowej, specyfiki pracy służb i inspekcji wchodzącej w skład tzw. administracji zespolonej. W międzyczasie miałam krótki epizod w pracy w dziennikarstwie, dzięki czemu poznałam warsztat pracy i specyfikę tego zawodu.

R.N.: Czy wspomniane doświadczenia przydatne sa w piastowaniu mandatu radnego, czy jest to zupetnie nowa materia? Przypomnę, iż zasiada Pani w trzech komisjach stałych rady, z czego przewodniczy Pani Komisji Statutowej i jest zastępca przewodniczącego Komisji Rodziny, Zdrowia i Spraw Społecznych.

M.R.-T.: Ależ oczywiście! Praca w Dolnośląskim Urzędzie Wojewódzkim pozwoliła mi się zapoznać z realizacją zadań z zakresu nadzoru i kontroli wojewody. Wiele wyniosłam z pracy w samorządzie studenckim, gdzie nauczyłam się zasad pracy w grupie, współdziałania, budowania atmosfery współpracy, ale też kompromisów i bycia asertywną. Nie stronię jednak od pracy i działań indywidualnych. W praktyce należy przecież łączyć zarówno walor pracy grupowej, jak i samodzielnej. Szczególnie to widać w pracy w komisjach branżowych rady, gdzie wiele spraw rozważa się w grupie kilku-kilkunastu członków. Inna specyfika pracy wiąże się z organizowaniem czy też prowadzeniem posiedzeń komisji. Oczywiście, przynależność do wspomnianych komisji podyktowana jest sprawami społecznymi, wśród których sprawy niepełnosprawności, rodziny, żłobków, przychodni czy osób starszych zajmują poczesne miejsce. Praca w komisji to zupełnie nowa rzecz, z którą nigdy wcześniej nie miałam styczności. Nastąpiła zmiana optyki. Z pytającego wcieliłam się w rolę referującego i odpytywanego. Proszę mi wierzyć, iż na początku nie było łatwo, tym bardziej że jestem najmłodszą przewodniczącą komisji statutowej.

Miasto. Pamięć i Przyszłość 1 (2016) ISSN 2543-621X 
R.N.: Skupmy się więc na Komisji Statutowej. Jaka jest jej rola, jakie są zadania tej komisji, w tym priorytety? Jak przedstawia się współpraca z radnymi i jaka jest Pani rola w tym gremium?

M.R.-T.: Komisja statutowa jest komisją techniczną. Jest jednak jedną z ważniejszych komisji rady, ponieważ to właśnie my musimy zaopiniować każdy projekt aktu, który na najbliższej sesji wchodzi pod obrady. Mowa tu, oczywiście, o opiniowaniu projektów uchwał pod względem ich zgodności z prawem i techniką legislacyjną. Istotnym zadaniem tej komisji jest czuwanie nad przestrzeganiem Statutu Wrocławia, opiniowanie zasad i trybu postępowania rady i jej organów wewnętrznych oraz występowanie z inicjatywą dostosowania aktów prawa miejscowego do prawa powszechnie obowiązującego, w tym zwłaszcza przygotowywanie projektu zmian Statutu. Dokonałam kilku zmian we współpracy z ekspertami współpracującymi z komisją, zespołem prawnym urzędu miejskiego oraz dyrektorami departamentów merytorycznych.

R.N.: Do Rady szła Pani z wieloma hasłami i pomysłami. Ile z tych idei i deklaracji udało się zrealizować?

M.R.-T.: Szłam do wyborów z prostym i realnym przesłaniem, aby Wrocław był dogodnym miejscem do życia na każdym jego obszarze. A więc realizacja idei zrównoważonego rozwoju miasta. Podczas kampanii obiecałam, że każdego dnia będę pracować na rzecz mieszkańców i troszczyć się o ich potrzeby. Moją pasją jest Wrocław. Moja filozofia na samorząd jest bardzo prosta - pomagać ludziom w tym, co najbardziej im doskwiera. Nie ma rzeczy bardziej istotnych niż to, żeby nasze najbliższe środowisko, otoczenie było przyjazne. Na pierwszy rzut oka tematy prozaiczne, jak remont chodnika, budowa placu zabaw, dodatkowe przyłącza do kanalizacji czy pomoc w rozwiązaniu trudnej sytuacji materialnej - to dla mnie priorytety.

Swój program wyborczy oparłam na trzech zasadniczych filarach. Po pierwsze, sport, rekreacja i kultura na naszym osiedlu. Skupiam się więc na budowie lub rewitalizacji boisk sportowych. Dla przykładu mam zamiar dokonać gruntownej przebudowy boiska przy ul. Wilanowskiej (obiekt przy Szkole Podstawowej nr 44), gdzie nastąpi ulepszenie infrastruktury i dostosowanie do wymogów wielofunkcyjnego obiektu. Teren przy Wilanowskiej to miejsce spotkań młodych ludzi, dzieci i wszystkich osób, które chcą aktywnie spędzać wolny czas. I to jest pierwszy punkt, który udało mi się zrealizować. Najbardziej mi na nim zależało! Pieniądze już są wydatkowane, a projekt jest w trakcie 
realizacji. Za rok planowane oddanie tej inwestycji do użytku. Doprowadziłam również do budowy boiska przy SP 83 przy ul. T. Boya-Żeleńskiego.

Drugim filarem jest komunikacja i transport miejski. Jest to obszar, który wymaga pracy, zaczynając od starań nad „przystankiem na żądanie” przy przychodni na Syrokomli, kończąc na budowie obwodnicy Psiego Pola. Małymi krokami staram się również usprawnić życie mieszkańców. Jest to również priorytet dla całego miasta, ze względu na historyczną zabudowę i pierścieniowy układ komunikacyjny. Walczymy teraz o dodatkowe zabezpieczenie przejazdu kolejowego w Pawłowicach - już poszła interpelacja w tej sprawie.

Trzecim filarem jest polityka prorodzinna, żłobki i przedszkola. W tym obszarze udało się dokonać chociażby budowy przedszkola przy ul. Okulickiego, tj. 8-oddziałowego budynku wraz z zagospodarowaniem terenu wokół niego. Przedszkole powinno być wybudowane do 30 listopada 2017 r. Mam tam jeszcze dodatkowy pomysł: chcę, aby plac zabaw był otwarty dla mieszkańców z Pawłowic i Zakrzowa. 12 sierpnia br. złożyłam swój własny projekt uchwały w sprawie przyjęcia programu polityki zdrowotnej „Leczenie niepłodności metodą zapłodnienia pozaustrojowego - in vitro dla mieszkańców Wrocławia w latach 2017-2019". Projekt jest reakcją na wygaszenie Narodowego Programu Leczenia Niepłodności metodą in vitro, które nastąpiło 30 czerwca. Na konferencji prasowej przekonywałam, że to właśnie nasze miasto powinno być kolejnym, które wspomoże wszystkie pary, które starają się o dziecko i mają z tym problemy. Jesteśmy w trakcie zbierania głosów poparcia pod tą uchwałą - prawdopodobnie może być to jeden z najważniejszych projektów dla wrocławskich rodzin.

R.N.: Wiele tematów, nad którymi Pani pracuje, dotyczy tzw. mikroskali miasta. Jak Pani ocenia działalność rad osiedli? Czy Komisja Statutowa interesuje się ta problematyka? M.R.-T.: De facto tak. Jesteśmy członkami dużej, ponad 600-tysięcznej wspólnoty mieszkańców, ale żyjemy na 48 osiedlach. Od lat trwają dyskusje nad ich reformą. Na przestrzeni ćwierćwiecza zebrało się sporo doświadczeń i wniosków. Od samego początku w tematykę rad osiedli zaangażowała się Komisja Statutowa. Zastanawiamy się nad zmianą ordynacji wyborczej czy też samej filozofii działania rad, aby je ożywić. Bezwzględnie czas na zmiany. Podobnie sprawa wygląda ze statutem, który jest jeszcze sprzed reformy samorządowej, bo uchwalony uchwałą Rady Miejskiej w 1996 r. Nasza mała „konstytucja” wymaga ponownego przepracowania pod wieloma względami, a jednym z najważniejszych będzie reforma rad osiedli.

Miasto. Pamięć i Przyszłość 1 (2016) ISSN 2543-621X 
R.N.: Może WBO spetnia swoja aktywizująca rolę, a inwestycje realizowane pobudza dziatanie rad? Jak Pani ocenia ten instrument?

M.R.-T.: Budżet obywatelski to proces, który umożliwia mieszkańcom dyskusję i bezpośredni wpływ na decyzje o przeznaczeniu części budżetu publicznego na przedsięwzięcia zgłoszone bezpośrednio przez obywateli. Bez wątpienia Wrocławski Budżet Obywatelski jest projektem nastawionym przede wszystkim na aktywizację mieszkańców. Urząd Miejski Wrocławia, dając mieszkańcom możliwość decydowania o ważnych dla nich inwestycjach, liczy na to, że wzmocni wśród wrocławian postawy obywatelskie. Wrocławski budżet partycypacyjny ma za zadanie pobudzać do aktywności mieszkańców i w oparciu o ich zaangażowanie budować społeczeństwo obywatelskie i wzmacniać dialog pomiędzy wszystkimi stronami biorącym udział w projekcie WBO. Byłam również zaangażowana w propagowanie WBO, z którego udało się u nas zrealizować kilka projektów, np. plac sportów przy al. Kasprowicza. Powstało tam wielofunkcyjne boisko, siłownia terenowa i urządzenia do kalisteniki. Finansujemy odpoczynek i rekreację przy stolikach szachowych, gry integracyjne. Stworzyliśmy ogólnodostępny teren odpoczynku i rekreacji przed Szkołą Podstawową nr 98 im. Piastów Wrocławskich, który służyć będzie uczniom i mieszkańcom Psiego Pola.

R.N.: Jesteśmy w połowie kadencji. Jak ocenia Pani półmetek obecnej RMW i co według Pani zasługuje na podkreślenie?

M.R.-T.: Samorząd to żywy i twórczy podmiot. Świadczą o tym chociażby ostatnie zmiany w składzie Rady Miejskiej, gdzie wyodrębnił się nowy klub, który wszedł w koalicję z KRRD i PO. W tej kadencji przypadło 25-lecie naszego samorządu i huczne obchody z tym związane. Przygotowujemy się do poważnych wydatków na edukację. Oświata we Wrocławiu staje się jednym z priorytetowych zadań - zostanie na to przeznaczony prawie miliard złotych. Dodatkowym wyzwaniem będzie dostosowanie się do zmian zaproponowanych przez rząd, m.in. spowodowanych wycofaniem 6-latków ze szkół. W tej kadencji priorytetem są inwestycje drogowe. W samym tylko 2016 r. z budżetu miasta przeznaczone zostanie na to ok. $620 \mathrm{mln}$ zł. Bieżący rok zdeterminowany jest wydarzeniami związanymi z Europejską Stolicą Kultury, a co za tym idzie - szeregiem inwestycji, które prowadzi się w mieście od lat. To jedna z najbardziej istotnych i znaczących imprez tej kadencji, choć nie jedyna. W szczególności mam na myśli przygotowania miasta do World Games 2017 i budowę oraz rewitalizację obiektów sportowych, takich jak Stadion Olimpijski, basen na ul. Wejherowskiej. Na koniec podkreślę wartość

Miasto. Pamięć i Przyszłość 1 (2016) ISSN 2543-621X 
budżetu obywatelskiego, który w obecnej kadencji zyskał na znaczeniu w oczach tak władz, jak i samych mieszkańców. Szereg realizowanych inwestycji jest tego namacalnym przykładem.

R.N.: Kończąc, zapytam o ustawodawstwo samorządowe. Gdzie widzi Pani potrzebę zmian i nowelizacji przepisów?

M.R.-T.: Poruszył pan niebywale istotny wątek! Postulować należy o zmiany mające wzmocnić status organizacyjno-prawny skarbnika i sekretarza, jako jednych z najważniejszych pracowników samorządowych. Dotyczy to również zakresu organizacji i funkcjonowania urzędu, zarządzania zasobami ludzkimi oraz zarządzania finansami i budżetem. Należy zdefiniować pojęcie „pracownik samorządowy” i „pracodawca samorządowy” oraz "urzędnik samorządowy”, jak i opracować nowy wykaz stanowisk pracowników samorządowych. Przydałoby się uszczegółowienie regulacji prawnych w zakresie podnoszenia wiedzy i kwalifikacji zawodowych pracowników samorządowych. Odnośnie do samych organów samorządowych należy przedyskutować ich kadencyjność. Ostrożna jestem w postulatach lansujących ideę bezpośrednich wyborów starostów i marszałków. Kluczową sprawą są jednak zadania i finanse. W tym ostatnim przypadku samorządy powinny mieć większą możliwość kształtowania źródeł dochodów własnych pochodzących z podatków lokalnych i wpływów z podatków PIT i CIT. Jest też szereg innych tematów wartych rozpatrzenia. Kilka tygodni temu byliśmy z wizytą za naszą wschodnią granicą, u radnych miejskich ze Lwowa. Wiele rozwiązań mnie tam zaskoczyło i dało zupełnie inne spojrzenie na nasze polskie rozwiązania. Mimo naszych niedoskonałości i niedociągnięć oni chcą brać z nas przykład, czują naszą pomoc i wsparcie.

\section{R.N.: Dziękuję za rozmowę.}

